International Journal of Social Sciences and Humanities
Available online at http://sciencescholar.us/journal/index.php/ijssh
Vol. 3 No. 2, August 2019, pages: 105 111
e-ISSN: 2550-7001, p-ISSN: 2550-701X
https://doi.org/10.29332/ijssh.v3n2.301

\title{
Problems of Learning and Pedagogical Intervention
}

Eduardo Sornoza Menéndez a, Maria Elena Moya Martinez ${ }^{\text {b }}$
Article history: Received 18 December 2018, Accepted: 30 April 2019, Published: 26 July 2019
Correspondence Author a ${ }^{\text {a }}$ Abstract
$\begin{aligned} & \text { Evers Mark teacher must be trained and solve any training difficulties that arise in } \\ & \text { the classroom, therefore, the work focuses on learning and intervention } \\ & \text { problems. The bibliographic revision was used as a method, in research a } \\ & \text { number of aspects of relevance to work were observed, in this way, learning } \\ & \text { problems were taken into accounts, such as dyscalculia and dyslexia. }\end{aligned}$

Keywords

dyscalculia;

dyslexia;

learning;

performance;

school;

e-ISSN: 2550-7001, p-ISSN: 2550-701X ${ }^{\odot}$ Copyright 2019. The Author. SS Journals Published by Universidad Técnica de Manabí. This is an open-access article under the CC BY-SA 4.0 license

(https://creativecommons.org/licenses/by-sa/4.0/) All rights reserved.

\section{Contents}

Abstract

1. Introduction.

2. Materials and Methods

3. Results and Discussions

3.1 Learning problems

3.2 Learning disorder .

3.3 How to detect learning problems.

108

3.4 Pedagogical intervention

108

4. Conclusion

109

Acknowledgements.

109

References

Biography of Authors

a Pontificia Universidad Católica del Ecuador, Portoviejo, Ecuador

b Pontificia Universidad Católica del Ecuador, Portoviejo, Ecuador 


\section{Introduction}

The learning problems that are currently increasing, because students have little interest in learning, It is impossible for students to think in the same way inside the classroom, you can find diversity of style of preparation, they do not pay attention to the teacher's recommendations, they do not speak correctly, these difficulties are seen daily in a school, by the lack of consideration of the parents to the child or of the teachers towards the students.

The learning difficulties faced by students and teachers have been studied by personnel trained in the specialty of the problem in the study center, which is why it is difficult to give a result of the involved by the opinions of various people in the establishments, the DECE department is being integrated, in order to facilitate the diagnosis of the students, and put into practice in the teaching work in the improvement of education.

Being aware that learning problems bring repercussions as a consequence, that is why to achieve knowledge in students, the teacher must take into account the content is well explained and mastered on the topic to be addressed, the educator has to manage many methodological strategies in the classroom, which are consistent with the class that is teaching in those pedagogical hours, and that way the student will pay attention and achieve that he understands the subject, are factors that currently occur (Macías et al., 2018; Suastra \& Ristiati, 2017).

The teaching-learning process is very complicated because other internal and external factors intervene, which is why it is always complicated to meet the objective set for each unit of study, but this process involves a practice of empowering education in order to achieve adapt the student in this process and achieve the goal that was raised at the beginning of a new topic.

\section{Materials and Methods}

For the development of the research work the deductive inductive methodology was applied since the inquiry was organized from the general to the particular; likewise, methods of analysis and synthesis were applied, with which the information was analyzed through a reflexive critical analysis of the collected exploration.

\section{Results and Discussions}

\subsection{Learning problems}

The next point to deal with is the problem of learning, often in schools, because of the student's deficiency, it can also affect the child in their school benefit. The obstacles or difficulties in the teaching field are presented consecutively in the establishment, since teachers are often heard to say that some of the students show different behavior patterns from the common one, for example, that they are somewhat distracted, or that they do not have an academic performance of excellence and on the contrary they get distinguished by their low qualifications; "Will it be that the teachers have been concerned to know what this is all about? Have they looked for ways to support them? Do they know what the learning problems are and what characteristics does a subject who suffers have? How to treat them? ? "(Ramírez, 2011). When answering these questions, mainly, the teacher needs to question what is learning, as well as their styles and the importance of this within the individual; In this way, he will later be able to identify the characteristics that will help him identify and recognize possible problems.

Despite the fact that learning problems are very common in schools, especially in the basic ones, teachers are not aware of the problems that affect the educational population, when students show indecent behavior in the group it is thought that they are disorganized, without paying due attention to the problems that affect 
them in the academic environment or in the home, when these problems are detected they must pay attention, to know what disturbs them (Mahendra, 2016; Ginaya et al., 2018).

The author of this article also mentions that the complications within the learning that arise due to school setbacks, would be thanks to the combination of a set of external factors to the student, which is within the family or social context, although perfectly You can find these two factors or contexts presented at the same time, in some cases you may also find yourself involved, which may be caused by the application of inappropriate practices. When explanations of certain occurrences of School Problems are given, it is very seldom feasible to establish a specific cause, which is why the lack of specificity in their mention arises, since they tend to originate from a number of reasons, each one with a very relative importance, and in turn they feed and they are given simultaneously and reciprocally (Suryasa et al., 2017).

About the difficulty that many students have in the educational field, it is due to factors that intervene in the teaching process, the repercussion that the students can have is the little interest of the teachers to improve the faults of the students, other cases that Influences are dysfunctional homes which is one of the most common problems in education, learning difficulties are also affected by the various disability problems of schoolchildren who have not yet been detected to start with curricular adaptations and seek an educational improvement.

\subsection{Learning disorder}

With regard to learning, disorders are very common in the academic field, one in 10 children suffer from this disease, which attacks school performance, they have very slow learning, if not detected in time this will last for all life. Diéguez (2010), mentions that according to a purely practical perspective, we have been able to select "three large diagnostic groups", in which we find: "dyslexia (disorder of reading and writing), dyscalculia (also called math disorder), and it is a subtype of non-verbal AT) and the disorders of non-verbal instruction (a big box where several disorders are included".

Simultaneously the learning disorders that are selected, are the most common they find in schools, some already diagnosed and others in the process of diagnosis, it is being analyzed that part of the procedure of the human being is affected so that these tumults of learning occur, it is believed that it occurs due to an abnormality in the nervous system, the alterations must be detected in time because it makes them very serious

Dyslexia is a difficulty that affects the development of the child during his studies, Para (Carratalá, 2013), one could get to realize that it is a disorder of the language of specific representation, this can be characterized by those who consider the complication to the moments of decoding the words. These difficulties are often not expected, and it can be said that they would not be the result of an evolutionary nature in general or of some wear and tear.

With regard to the previous text, it could be said that dyslexia is a disorder that affects children especially, it is difficult for them to perform a certain reading because they cannot pronounce all the words, as they do not have mastery of reading and writing. It would make school performance difficult, many teachers who ignore the situation, they dismiss the student as useless, without knowing that their learning problem does not capture the classes as their classmates, this ignorance is observed daily in schools.

Dyscalculia is a disorder that occurs to the child in the first years of studies According to (Tustón, 2009). It is expressed through the weakening and/or loss of the ability to calculate, as well as maneuvering with numerical character symbols or performing simple operations. In general, the deficit is blamed, from the sequential, cognitive and verbal.

Advancing our reasoning dyscalculia is a problem that often occurs in schools, this makes children lose the notion of mathematics, it also affects the ability to establish or write exercises especially in arithmetic, the impact is can be perceived in the low performance of the student, is due to the lack of attention of the parent or the teacher of the institution so that you can help the student with a better performance in mathematics that can be difficult to conceive in the process of teaching-learning.

It is a natural and logical consequence of the learning dynamics, so it is not considered pathological, and therefore, the teacher should continue with the common teaching plan, with the conviction that the process will be normalized through review and fixation exercises (Vergara, 2011). When there is dyscalculia and they

Menéndez, E. S., \& Martinez, M. E. M. (2019). Problems of learning and pedagogical intervention. International Journal of Social Sciences and Humanities, 3(2), 105-111. https://doi.org/10.29332/ijssh.v3n2.301 
are detected, it is necessary to warn the people indicated for the proper treatment with the scholar, and thus have significant knowledge.

\subsection{How to detect learning problems}

For what refers to the learning problems the teacher is not appropriate to give conclusions only makes a presumption, who gives the diagnosis would be a professional in the branch. as he emphasizes. Etchepareborda (2002), One of the first indicators of the difficulties caused by dyslexia is the phonographic decoding when the child tries to relate signs to the phonological order when articulating sentences. In the process, the infant tries to visually recognize the messages and associate them with the name of the things, this identification exceeds the ocular perception, since one must be able to differentiate the graphemes according to their pronunciation and later meaning, it does not depend only on the figure, but of psycholinguistic valence.

In order to better understand the learning disorder and to detect them, we will make an analogy of the following topic. In students the first thing to identify is when they begin to decode the words, establish readings and make many associations of numbers, since these two problems that were mentioned at the beginning is the first cause of disorder in schools, once the teacher finds fault in the writing is advisable to send the child to the guidance department and follow the due process, so that they give the diagnosis of the patient.

\subsection{Pedagogical intervention}

The pedagogical intervention in teaching processes should be treated as much as possible is to start with the monitoring of the inconvenience that students have. Gallardo (2011), states during interventionist studies of the prevention of aggressive behaviors in infants, it is noticeable the recurrence to the approach of alternatives to influence family agents, the way of parenting, the types of authority and the classes of mother and father relationships, and sons. These proposals are intended to involve the elementary mediator parents to achieve changes in the behavior of the children, improving discipline, achieving clear and defined rules. Likewise, it is evident that interposition programs are developed for the participation of children, family, and teachers because by reinforcing the work with these environments the results are eloquent.

It is necessary to emphasize that when children are given due intervention due to unusual behavior or failure in school performance, it is necessary to present the plans with the appropriate curricular adaptations, it is essential that the parent is very attentive to any problem of learning that is detected in the first years of studies, once revealed the problems in an education center will begin to work with the student diagnosed, and it is thus that adequate work will be achieved. In Table 1, the analysis made by some authors was shown.

Table 1

Results of the authors consulted

\begin{tabular}{llll}
\hline Autor & Año & Tema & Resultado \\
\hline Carratalá & 2013 & Dyslexia learning problems. & $\begin{array}{l}\text { These disorders occur in children and } \\
\text { tend to have poor school performance. }\end{array}$ \\
Diéguez & 2010 & Learning disorders & $\begin{array}{l}\text { When a child with a disorder is } \\
\text { identified, it is convenient to perform th } \\
\text { appropriate treatment to achieve } \\
\text { significant learning. }\end{array}$ \\
Etchepare & 2002 & $\begin{array}{l}\text { Early detection } \\
\text { From the dyslexia and therapeutic } \\
\text { approach }\end{array}$ & $\begin{array}{l}\text { Children are detected in phonographic } \\
\text { detection problems, complications in } \\
\text { detecting signs and in speech. }\end{array}$
\end{tabular}




\begin{tabular}{|c|c|c|c|}
\hline Gallant & 2011 & $\begin{array}{l}\text { Infant aggression: } \\
\text { A proposal for pedagogical intervention. }\end{array}$ & $\begin{array}{l}\text { They are sudden changes of the children } \\
\text { these are in the school or in familiar } \\
\text { surroundings. }\end{array}$ \\
\hline Ramírez & 2011 & Learning problems at school. & $\begin{array}{l}\text { It can be identified when the student has } \\
\text { a low school performance. }\end{array}$ \\
\hline Rosemary & 2005 & $\begin{array}{l}\text { Difficulties in learning: Unification of } \\
\text { diagnostic criteria. }\end{array}$ & $\begin{array}{l}\text { After an appointment with the DECE } \\
\text { department, the student's determination } \\
\text { can be given to perform an adaptation. }\end{array}$ \\
\hline Tustón & 2009 & $\begin{array}{l}\text { The dyscalculia and the learning of } \\
\text { mathematics in the children of the } 5 \text { th. }\end{array}$ & $\begin{array}{l}\text { It does not allow to make mathematical } \\
\text { problems in the students, this begins at } \\
\text { the age of } 5 \text { years. }\end{array}$ \\
\hline Vergara & 2011 & $\begin{array}{l}\text { Methodological strategies for the } \\
\text { academic improvement of students with } \\
\text { dyscalculia problems of the } 7 \text { th year of } \\
\text { general basic education. }\end{array}$ & $\begin{array}{l}\text { The teacher performs the methodologies } \\
\text { depending on the diagnosis he has in the } \\
\text { classroom, to achieve significant } \\
\text { learning. }\end{array}$ \\
\hline
\end{tabular}

The teacher performs the methodologies depending on the diagnosis that he has in the classroom, to achieve meaningful learning.

This aspect is extremely fundamental, given that those students who lack basic illustrations, will have higher probabilities of failing in higher levels of instruction and, for that reason, it is not supposed, essentially, an improvement in their quality of life. However, within these indexes they assume something general, which does not specify, it is precise because of learning problems, which could well be a cause for this tendency. It can also be mentioned that excellent or good training will achieve quality education, the acquisition of knowledge, skills, and attitudes that have an intrinsic value and contribute to economic and social development.

\section{Conclusion}

Learning problems are very common in schools, they are detected with early years either because of the student's lack of interest in instruction or because of low academic averages, it can also affect to an educator with a very high school performance, with regard to the subject schools should pay attention to students who have been detected with dyslexia and dyscalculia to achieve a required learning.

As for the evaluations, they have to be according to the student who has detected a learning problem so that they can develop their skills and achieve significant learning. The teachers must help the student so that they have confidence and achieve the active participation of the student, and also in terms of the methodology that is understood so that the student has a motivation and achieve the objectives proposed by the teacher.

\section{Acknowledgments}

The author would like to thank the editorial boards' team of IJSSH for their valuable time, support and advice in completing the present study.

\footnotetext{
Menéndez, E. S., \& Martinez, M. E. M. (2019). Problems of learning and pedagogical intervention. International Journal of Social Sciences and Humanities, 3(2), 105-111. https://doi.org/10.29332/ijssh.v3n2.301
} 


\section{References}

Carratalá, S. (2013). Dyslexia learning problems. Scientific article, 1 (1), 22-28. Retrieved from http://cnoo.es/download.asp?file=media/gaceta/gaceta483/cientifico1.pdf.

Diéguez, M. Álvarez, A. (2010). Learning disorders. (University monograph). Autonomous University of Barcelona, Spain. Retrieved from https://www.sccalp.org/documents/0000/1526/BolPediatr2010_50_043-047.pdf.

Etchepareborda, M. 2002, p.15). Early detection of dyslexia and therapeutic approach. Journal of Neurology of $\begin{array}{lllll}\text { Buenos } & \text { Aires, } & 34 & 13-23 . & \text { Recovered de }\end{array}$ https://www.orientacionandujar.es/wpcontent/uploads/2014/11/Detecci\%C3\%B3n-precoz-de-ladislexia.pdf.

Gallardo, A. (2011). Child aggression: a proposal for intervention and pedagogical prevention from school. Colombian scientific article, 1 (33), 295- 314. Retrieved from http://revistavirtual.ucn.edu.co/index.php/RevistaUCN/article/download/6/12.

Ginaya, G., Rejeki, I. N. M., \& Astuti, N. N. S. (2018). The effects of blended learning to students' speaking ability. International Journal of Linguistics, Literature and Culture, 4(3), 1-14.

Macías, EIP, Cedeño, HAC, \& Chávez, GMR (2018). Importance of Improving Resilience in Teaching-Learning Process of Students with Disabilities. International Research Journal of Management, IT and Social Sciences , 5 (2), 120-128.

Mahendra, I. W. E. (2016). Contextual learning approach and performance assessment in mathematics learning. International Research Journal of Management, IT and Social Sciences, 3(3), 7-15.

Ramírez, C. (2011). Learning problems at school. Iberoamerican scientific journal, 13 (1), 43-51. Retrieved from https://dialnet.unirioja.es/descarga/articulo/4777933.pdf.

Suastra, I. W., \& Ristiati, N. P. (2017). Problems faced by teachers in designing and implementing authentic assessment in science teaching. International Research Journal of Engineering, IT \& Scientific Research, 3(4), 27-36.

Suryasa, I. W., Prayoga, I. G. P. A., \& Werdistira, I. W. A. (2017). An analysis of students motivation toward English learning as second language among students in Pritchard English academy (PEACE). International Journal of Social Sciences and Humanities, 1(2), 43-50. https://doi.org/10.29332/ijssh.v1n2.36

Tustón, d. (2009). The dyscalculia and the learning of mathematics in the children of the 5th. Year of basic education of the school "Ecuador" of the city of Ambato. Technical University of Ambato. Ambato, Ecuador. Retrieved from http://repo.uta.edu.ec/bitstream/123456789/2265/1/tebp_2009_21.pdf.

Vergara, G. R., Vijayakumar, S., Kholmovski, E. G., Blauer, J. J., Guttman, M. A., Gloschat, C., ... \& McGann, C. J. (2011). Real-time magnetic resonance imaging-guided radiofrequency atrial ablation and visualization of lesion formation at 3 Tesla. Heart Rhythm, 8(2), 295-303. https://doi.org/10.1016/j.hrthm.2010.10.032 


\section{Biography of Authors}

Eduardo Sornoza,
as a teacher in the Fiscal Education Unit Portoviejo, It is a bachelor's degree in
Education Sciences with a General Basic Education.
Email: sornozamenendez@yahoo.com

Menéndez, E. S., \& Martinez, M. E. M. (2019). Problems of learning and pedagogical intervention. International Journal of Social Sciences and Humanities, 3(2), 105-111. https://doi.org/10.29332/ijssh.v3n2.301 